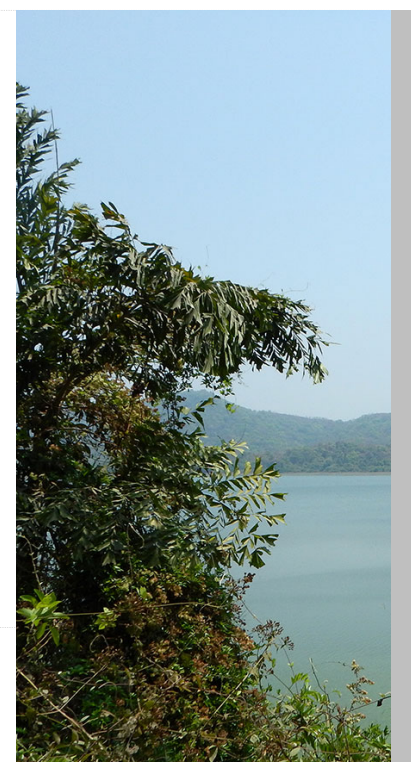

\title{
OPPORTUNITIES FOR INVESTMENT IN THE SOCIETAL VALUES PROVIDED BY SANJAY GANDHI NATIONAL PARK, INDIA
}

\author{
Mark Everard ${ }^{1 *}$, Anwar Ahmed $^{2}$, Nudrat Zawa Sayed ${ }^{3}$ and Shivaji Chavan ${ }^{3}$ \\ * Corresponding author: mark.everard@uwe.ac.uk \\ ${ }^{1}$ Univesity of the West of England, Bristol BS16 1QY, UK \\ ${ }^{2}$ Sanjay Gandhi National Park, Mumbai, Maharashtra, India \\ ${ }^{3}$ Wlildlife and We Protection Foundation, A-104, Madhuvan Co. Hsg. Soc, Shimploi-Gorai Road, \\ Off Link Road, Borivali west, Mumbai 400 091, Maharashtra, India
}

\section{ABSTRACT}

Sanjay Gandhi National Park (SGNP), surrounded by the megacity of Mumbai, India, is subject to high anthropogenic pressures. However, it constitutes an important 'green lung' and water source, supporting biodiversity, tourism, recreation, and additional benefits both locally and remotely. To safeguard and enhance the park ecosystem, there is a need to recognise and demonstrate the diversity of values associated with these multiple benefits, identify potential conflicts, and establish the management measures necessary to protect them. This study explores outcomes from SGNP across a systemically connected range of ecosystem services, and the geographical scales over which service benefits accrue. This informs potential novel 'payment for ecosystem services' (PES) opportunities. The protected status of the landscape is reflected in low values from provisioning services (material or energy exploitation), but substantial values from supporting (such as habitat for wildlife), regulating (including global climate, microclimate and hydrological regulation) and cultural (particularly tourism) services. However, direct resource exploitation by communities inhabiting the park is limited. Some ecosystem services were identified as ready for PES implementation (for example, water supply), others require further development (including contributions to the peripheral urban microclimate), while many services have no or limited PES potential (such as wood or aggregate extraction, prohibited under park regulations).

Key words: Ecosystem services, payment for ecosystem services, values, Mumbai, conservation, protected areas

\section{INTRODUCTION}

Ecosystems and ecosystem services are constantly changing, driven by demographic, economic, sociopolitical, technological, climatic and behavioural trends. The Millennium Ecosystem Assessment (2005) reported that 60 per cent of ecosystem services are degraded globally. Continuing and accelerating deterioration of ecosystems and their services erodes the foundations of economies, livelihoods, food security, health and quality of life (Brondizio, 2019). Protected areas tend to change more slowly than landscapes subject to more direct human pressures, serving important roles in conservation of species and landscape diversity, ecosystem services and wider societal benefits (Secretariat of the Convention on Biological Diversity, 2008). Ecosystem service production by protected areas can be significant. For example, an ecosystem service study found that India's Tiger Reserves provide a wide range of ecological, social and cultural benefits of substantial cumulative economic value (Verma et al., 2015). Although Hummel et al. (2019) concluded that an ecosystem services approach has scarcely been used in protected area management, and contested uses of ecosystem services may contribute to a 'conservation against development' model in some places (Martín-López et al., 2011), Figgis et al. (2015) document increasing convergence between biodiversity conservation and ecosystem service protection in protected area planning and management. Protection of natural capital and ecosystem services can constitute a cost-effective means to sustain the benefits of protected areas to human wellbeing (Ekins et al., 2003). Nevertheless, disbenefits may result when people are displaced, denied traditional resource use rights, or where there is uneven distribution of benefits and disbenefits between societal sectors (Brockington \& Wilkie, 2015).

Historically, many ecosystem benefits have been regarded as 'free' and so have often been overlooked, unintentionally or wilfully, compromising conservation and development goals. Early conceptions of 'payment 


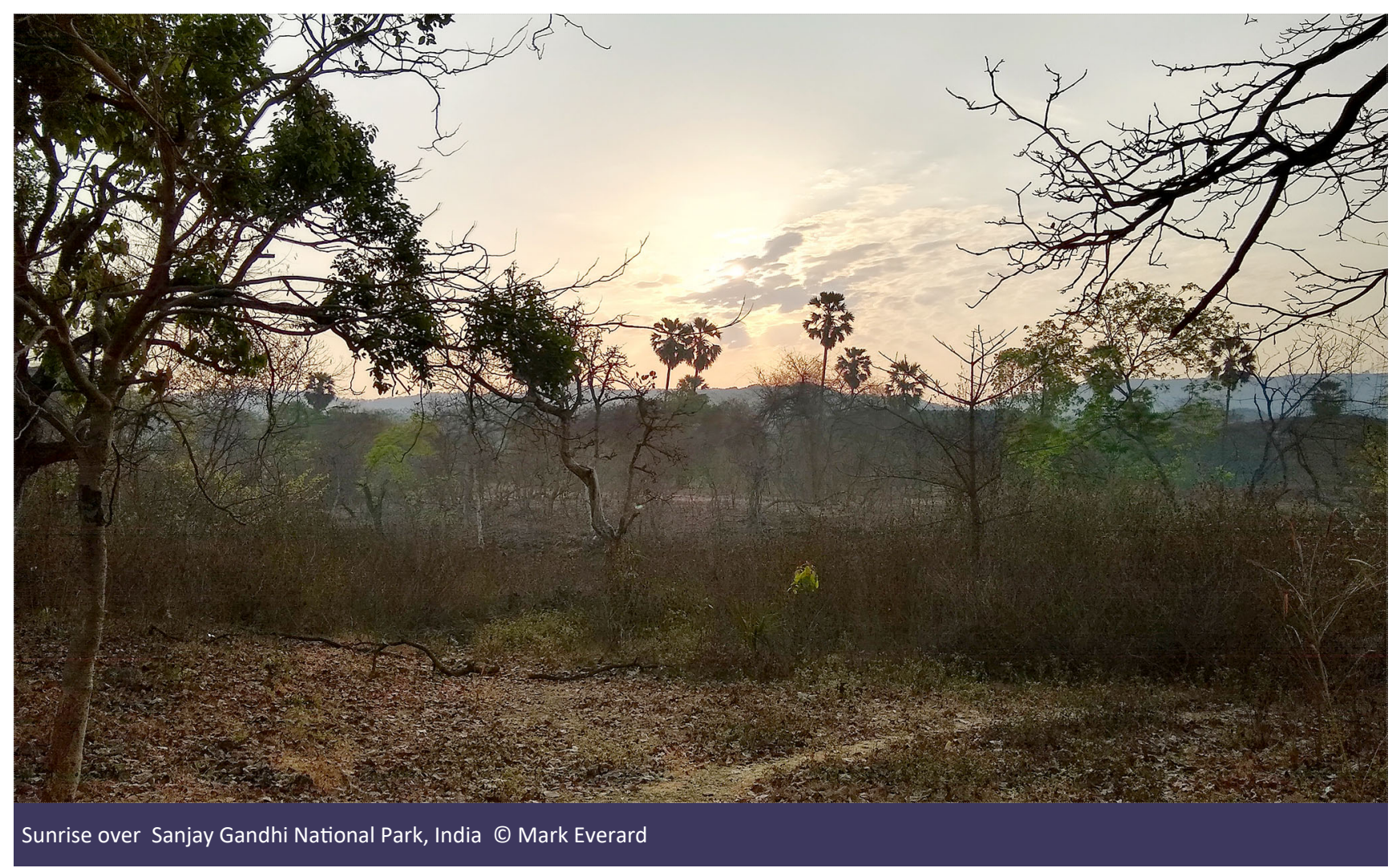

for ecosystem services' (PES) were as voluntary markets providing financial incentives for management practices aimed at protecting or increasing production of desirable services (for example Wunder, 2005), embodying the concept that those who provide services should be paid for doing so by those who consume them (Engel et al., 2008). By 2010, thousands of PES or PESlike arrangements addressing a range of service types were established globally at scales from the local to the international (OECD, 2010; Pattanayak et al., 2010). Environmental and forest policies have expanded the use of PES principles to address multifunctional objectives of ecosystem management (Merlo \& Briales, 2000; Wunder et al., 2005; Cubbage et al., 2007), including increasing use of PES to address conservation and environmental goals. Examples include the Miaro Forest Corridor project in Madagascar (WWF, 2009) and the Pago por Servicios Ambientales (PSA) scheme in Costa Rica (FAO, 2007). PES may also span and reconcile rural lifestyles and livelihoods (Hubermann, 2009), for example in management of Nyungwe National Park in Rwanda (Gross-Kamp et al., 2012). However, potential conflicts can arise in terms of distributional equity, for example as demonstrated in a case study in SGNP exploring denial of access of tribal communities to the natural resources and their estrangement in favour of the values of more privileged constituencies (Sen \& Pattanaik, 2015).
The thinking about PES and its growing application across the global South has evolved to recognise wider aspects of the valuation of nature, the development needs of rural communities, the creation or engagement of relevant institutions, and dialogue about the distribution of benefits (Shapiro-Garza et al., 2020a). This is in recognition and accommodation of substantially varying global and local perspectives relating to relative values and distributional benefits of PES mechanisms (Nelson et al., 2020). PES programmes based on narrow neoclassical economic principles risk conceptualising ecosystems as 'factories' for desirable commodity production, Shapiro-Garza (2020b) favouring instead a Compensation for Ecosystem Services (CES) model offering compensation for sustainable stewardship and labour of rural communities. As one example, Vietnam's Payments for Forest Environmental Services policy differs substantially from the original simplistic market model, incorporating strong state involvement in transfers of money to households in upland watersheds targeted for forest protection (McElwee et al., 2020). In this Vietnamese model, payments are not linked to market rates, and are also non-conditional, albeit that clarity about outcomes is hampered by lack of monitoring.

Jackson and Palmer (2014) argue that a fundamental reshaping of the PES concept is required, challenging 
what is valued and by whom, to better resolve different scales of benefit realisation from natural systems. There is consequently a growing call for more nuanced analyses of the ways in which PES can become coproduced, to better integrate benefits for both nature and the needs and values of local communities, including non-market values, addressing diverse manifestations of power (Upton, 2020). Consequently, PES programmes are increasingly evolving to reflect multiple stakeholder demands, now rarely operating in pure market form and instead addressing rural development particularly of historically marginalised groups in delivering linked sets of goals (vonHedemann, 2020). Potential conflicts introduced by PES arrangements between conservation and development may be resolved by negotiation, facilitated by appropriate institutions between those focused on highlevel outcomes, such as erosion regulation or wateryielding upper catchment protection, and the livelihood needs and values of rural stakeholders ( $\mathrm{He}, 2020$; Joslin, 2020). 'Wise use' of ecosystems (sensu Ramsar Convention Secretariat, 2007) can, for example in a case study of rubber tapping in Brazil, provide economic value to local people whilst facilitating wider forest protection (Greenleaf, 2020). However, lack of, or weak, local institutions can fragment buy-in to PES arrangements by affected local communities, creating problems in areas of uneven land tenure (Corbera et al., 2020).

This study addresses the perceived ecosystem services provided by Sanjay Gandhi National Park (SGNP), popularly known as Borivali National Park, located in Borivali, Mumbai, in the Indian state of Maharashtra (Figure 1). Surrounded on three sides by the cities of Mumbai and Thane, SGNP is subject to high anthropogenic pressures. This creates a biologically fragmented 'fenced island' ecosystem that is, nonetheless, rich in biodiversity, tourism and recreational values. It also represents a 'green lung' within the intensively urbanised surroundings, and serves as a water source for the city as well as encompassing the sources of the four rivers of Mumbai. SGNP provides additional societal benefits, locally and more remotely, though prohibitions on resource use by communities within the park may be perceived as limiting the benefits they derive. Government investment in SGNP is significant, as are visitor numbers and revenues. However, there is a need to explore opportunities for investment from nontraditional sources, comprising beneficiaries of formerly unrecognised ecosystem services, to further recognise, safeguard and enhance the diversity of societal values provided by the park.
Many of the societal values generated by SGNP are currently substantially underappreciated or, more commonly, entirely overlooked, even by those that benefit substantially from them. This represents a major market failure. Inclusion of ecosystem service benefits within payment mechanisms for management activities in protected areas can potentially reduce dependence on government grants, ideally generating surplus money for reinvestment in community development activities. Analysis of the feasibility of establishing PES approaches in SGNP provides an opportunity to ascribe values to previously un-priced ecosystem services and their generally formerly overlooked societal and economic benefits. This study consequently aims to identify, in a semi-quantitative way, perceptions of the range of ecosystem services produced by SGNP, who benefits from them, and to identify services for which it may be possible to develop PES arrangements.

\section{METHODS}

\section{The study site}

SGNP occupies $103.68 \mathrm{~km}^{2}$ between longitude $72^{\circ} 53$ ” E to $72^{\circ} 58^{\prime \prime}$ E and latitude $19^{\circ} 8.8^{\prime \prime}$ to $19^{\circ} 21^{\prime \prime} \mathrm{N} ; 44.44 \mathrm{~km}^{2}$ in Thane District and $59.24 \mathrm{~km}^{2}$ in Mumbai Suburban District of Maharashtra State (Figure 1). An eco-

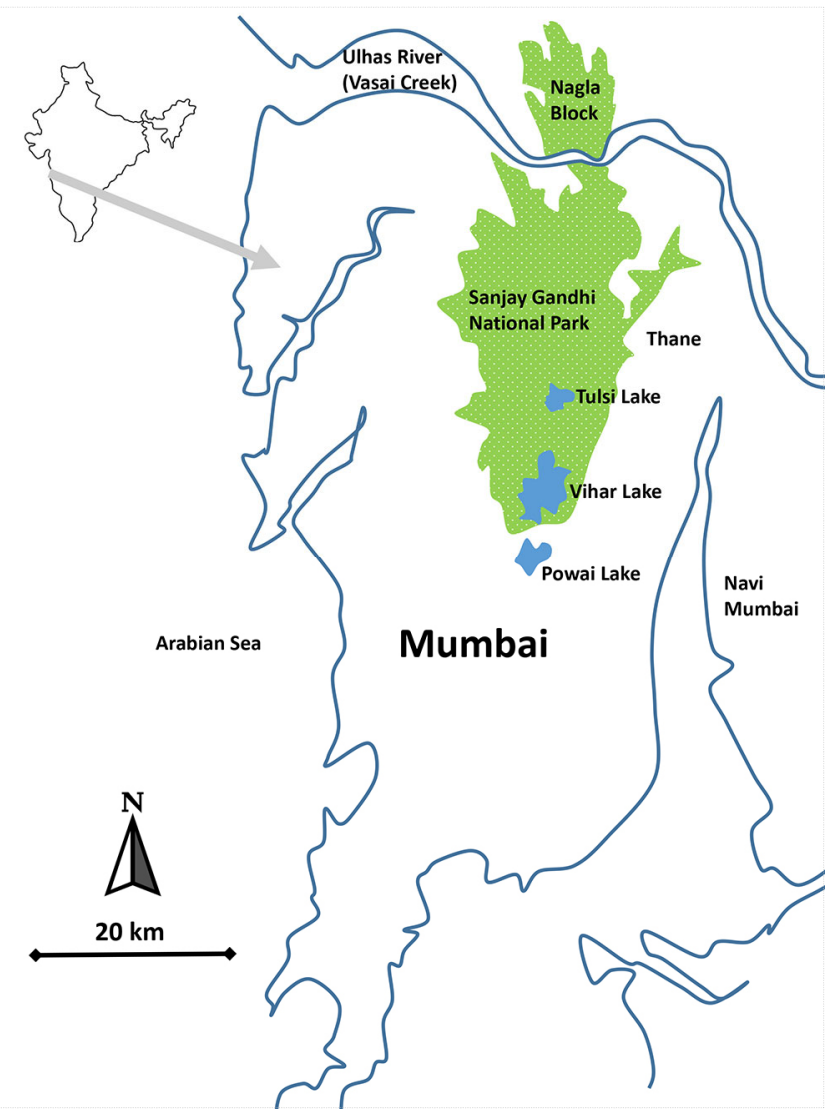

Figure 1. Location map of Sanjay Gandhi National Park 
sensitive zone around the parkland area was declared in January 1996 by Maharashtra Government Resolution No. WLP/1094/ OR 177/F-1, finally notified by the Ministry of Environment, Forest and Climate Change, Government of India, in December 2016 (MoEF, 2016). The entire park area is now under the administrative control of the Additional Principal Chief Conservator of Forest (Wildlife), Borivali.

Location is a key part of SGNP's unique characteristic. SGNP represents a tiny green tract amid a densely populated surrounding megacity. The city exerts multiple pressures from unplanned economic development, industrialisation and vehicular emissions contributing to escalating air pollution, and lacking sufficient green belt areas providing open spaces for people and the regulation of climate and air quality. Yet, though fragmented in places, the park encompasses substantial faunal and floral diversity. This includes a number of endangered species, and the park harbours one of the highest global densities of leopard (Panthera pardus), as well as providing recreational values scaling from local to national significance. The park is situated within the northern Malabar Coast of the Western Ghats biogeographic zone, one of the least represented by protected areas. It encompasses a diversity of forest types - moist teak forest, mangroves, mixed deciduous forest and sub-tropical hill forest - and grasslands.

The park's contribution to the water resources of Mumbai and Thane is highly significant. Two lakes and their catchment areas - Vihar Lake and Tulsi Lake neither ever drying up - are located within SGNP. Both supply water and provide water security during delayed monsoons. Four rivers of Mumbai - the Mithi, Poisar, Oshiwara and Dahisar Rivers - originate from SGNP. However, whilst clean within the park, all four rivers become grossly polluted once flowing into the surrounding city. SGNP's vegetation also plays important roles in reducing atmospheric pollution from urban anthropogenic activities, absorbing or helping break down aerial pollutants and settling fine particulate matter, thereby improving surrounding air quality, regulating local temperatures and sequestering substantial amounts of carbon (IUCN, 2015).

Forty-three padas (hamlets) comprising 1,795 families are located within the park (SGNP, 2012). Tribal residents are allotted rights to land and other resources under India's Scheduled Tribes and Other Traditional Forest Dwellers (Recognition of Forest Rights) Act, 2006 (also known as the Forest Rights Act or Tribal Rights Act). This Act redresses rights perceived as denied under former colonial-era forest laws.

\section{Assessment of societal values provided by SGNP}

Ecosystem service flows from SGNP were reviewed to assess opportunities for PES development. The framework of provisioning, regulating, cultural and supporting services, defined by the Millennium Ecosystem Assessment (2005) and adapted in the RAWES (Rapid Assessment of Wetland Ecosystem Services) approach adopted by the Ramsar Commission (Ramsar Convention, 2018), formed the conceptual framework. Although redefined as functions and omitted to avoid 'double-counting' in some reclassifications (for example TEEB, 2010; Braat \& de Groot, 2012), supporting services were explicitly considered recognising their importance in decisionmaking contexts due to their vital roles in the functioning, resilience and capacities of ecosystems to generate other services. Though developed as a rapid wetland assessment approach recognising practical time and resource constraints (McInnes \& Everard, 2017), RAWES is essentially adapted from a wider approach used extensively for a range of habitat types (for example by Everard, 2009; Everard \& Waters, 2012). RAWES enables the integration of different available and observable forms of knowledge (quantitative, qualitative, interviews with local stakeholders, expert judgement, etc.), informing semi-quantitative judgements of the perceived significance of each

\section{Table 1. Interviewees and the semi-structured interview approach}

$\begin{array}{ll}\begin{array}{ll}\text { Stakeholder group } & \text { Numbers and composition of interviewees } \\ \text { Villagers living in SGNP } & \mathrm{N}=43 \text { (One randomly selected household from the } 43 \text { padas identified in the } \\ \text { SGNP (2012) Management Plan; } 22 \text { female and } 21 \text { male respondents) }\end{array} \\ \begin{array}{l}\text { Ground staff of SGNP } \\ \mathrm{N}=6 \text { (2 forest guards from each of the Park's three ranges) } \\ \text { Officers of SGNP }\end{array} & \begin{array}{l}\mathrm{N}=6 \text { (District Forest Officer, two Assistant Forest Officers and three Range } \\ \text { Forest Officers) }\end{array} \\ \text { Tourists visiting SGNP } & \mathrm{N}=16 \text { (10 female and } 6 \text { male, randomly selected) } \\ \text { People living in the close vicinity of SGNP } & \mathrm{N}=9 \text { (heads of families living in the vicinity of the park, } 5 \text { male and } 4 \text { female) }\end{array}$




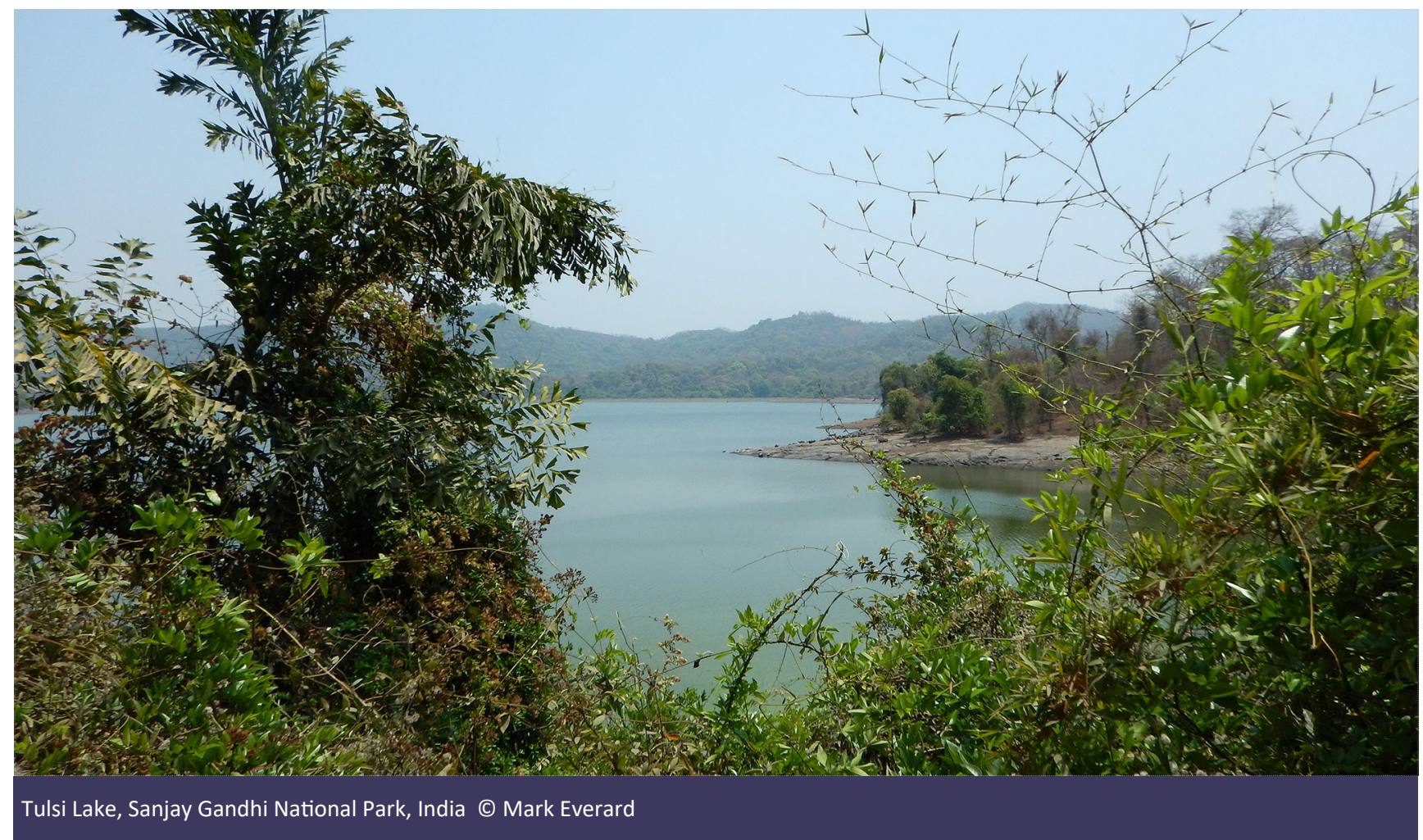

ecosystem service on a systemic basis, including geographical scales of benefit realisation. RAWES assessments can serve as an initial screening providing systemic context for subsequent quantitative assessments of targeted ecosystem services. They may be used in local or national policy frameworks and decision-making processes such as environmental impact assessments, and can provide a basis for identification of potential PES opportunities (McInnes \& Everard, 2017).

Evidence-gathering to populate this ecosystem services assessment was derived from the literature cited in this report (particularly in Supplementary Online Material 1), interviews with SGNP stakeholders, and the expert knowledge of the assessment team. Interviewees $(\mathrm{N}=80)$, described in Table 1 , were interviewed by the research team. Semi-structured interviews were conducted primarily in Hindi, where this was the interviewee's native language. Interviewees were asked about their use of each ecosystem service, though these were introduced in conversation in locally relevant terms rather than through a rigid questionnaire to better account for cultural differences between researchers and local people and the diversity of views of the interviewee group (following Everard et al., 2019). This approach enabled interviewees to respond freely rather than asking them to rigorously adhere to precise questions. Gender sensitivity was considered by selecting informal interviewers of the same gender as interviewees. Interviewees were asked for their consent to use their responses in anonymised form for research purposes, and were informed of their rights to withdraw from the study by contacting the interviewers.

Summarising production of the four ecosystem service categories at SGNP, the semi-quantitative importance of each service was scored on a scale from +1.0 (significantly positive) to -1.0 (significantly negative) with intermediate points at 0.5 (positive), o (neutral) and -0.5 (negative). Responses of 'not relevant' and 'unknown' were removed from analysis. Groups of ecosystem services were summed and divided by the number of relevant services per service category to derive an ecosystem services index (ESI), based on similar index methods by Butchart et al. (2010) and applied by McInnes and Everard (2017) and Everard et al. (2019). ESI is calculated using Equation 1, where 'nTOTAL' was adjusted to remove services that were not relevant in this specific context (e.g. waste disposal or fire regulation within SGNP). The potential ESI range is from +1 to -1 , calculated for each of the four ecosystem service categories, or as a compound value for all services.

\section{Equation 1.}

$$
\mathrm{ESI}=\frac{\sum\left(n_{+1.0}+n_{+0.5}\right)+\sum\left(n_{-1.0}+n_{-0.5}\right)}{\sum n_{\mathrm{TOTAL}}}
$$


This equation was also used to calculate ESIs for the four geographical ranges used in this assessment (local, city, national, international) for all 30 relevant services. Total ESIs for geographical scales can exceed 1.0 where benefits accrue across multiple scales.

\section{RESULTS}

The RAWES approach integrated evidence from publications cited in the body of this paper and Supplementary Online Material 1, stakeholder interviews and expert judgement, recognising perceived ecosystem service benefits and the geographical scales over which benefits arise. The various ecosystem services are enjoyed not only by tourists, researchers and educators within the park but, significantly, by the entire city of Mumbai and Thane. Many more benefits extend over national and international scales. These findings are summarised in Supplementary Online Material 2 with explanatory comments on how judgements were made.

Table 2 outlines ESI scores by ecosystem service category, and Table 3 outlines ESI scores for the geographical scales at which services accrue.

The ESI for provisioning services (0.42, accounted for by significant exploitation of water and limited use of food, fibre, fuel and ornamental resources) was the lowest for all ecosystem service categories, reflecting the policy of withholding exploitation of natural resources such as timber, aggregates, food, medicines and biochemicals, energy harvesting and waste disposal within the park. This clearly has substantial benefits in protecting the functioning of the park's diverse ecosystems and production of other services (maximum ESI of 1.00 for supporting services with 0.92 for regulating services). Cultural services are also substantial (0.79), addressing a range of values expressed as cultural heritage, tourism and recreation, aesthetics, spiritual and religious values, artistic inspiration, social relations, and education and research, experienced in varying ways and over different spatial scales by stakeholders including park residents, adjacent urban residents and other national and, in the case of tourism and research, international communities. It was not possible within the scope of this study to differentiate the perspectives of different stakeholder groups. Nor was it possible to conduct a sensitivity analysis as to whether, or to what degree, further controlled use of provisioning services by Indigenous communities under tribal rights could influence the flows of all ecosystem services.

ESIs for the geographical scales at which benefits accrue emphasise the substantial scale of benefit realisation locally $(\mathrm{ESI}=0.75)$ and to the adjacent city $(\mathrm{ESI}=0.67)$, with lower scores for national and international scales (ESIs of 0.23 and 0.22 respectively) for services that are nonetheless important (such as global climate regulation and tourism resource). The substantial ESI of 1.87 for combined scales demonstrates that many

Table 2. ESI scores for ecosystem service categories as defined by the Millennium Ecosystem Assessment (2005)

\begin{tabular}{|c|c|c|c|}
\hline Ecosystem service category & $\begin{array}{l}\text { Cumulative importance } \\
\text { scores }\end{array}$ & $\begin{array}{l}\text { Number of relevant services (out of total in } \\
\text { category) }\end{array}$ & ESI \\
\hline Provisioning & 2.5 & 6 (out of 9) & 0.42 \\
\hline Regulating & 10 & 11 (out of 14) & 0.91 \\
\hline Cultural & 5.5 & 7 (out of 7) & 0.79 \\
\hline Supporting & 6 & 6 (out of 6 ) & 1.00 \\
\hline Combined services & 24 & 30 (out of 36 ) & 0.85 \\
\hline
\end{tabular}

Table 3. ESI scores across the four geographic benefit realisation ranges

\begin{tabular}{lccc}
$\begin{array}{l}\text { Ecosystem service benefit } \\
\text { realisation range }\end{array}$ & $\begin{array}{c}\text { Cumulative importance } \\
\text { scores }\end{array}$ & $\begin{array}{c}\text { Number of relevant services (out of total } \\
\text { services) }\end{array}$ & $\begin{array}{c}\text { ESI } \\
\text { Local }\end{array}$ \\
$\begin{array}{l}\text { City } \\
\text { National }\end{array}$ & 22.5 & 30 (out of 36) & 0.75 \\
International & 7 & 30 (out of 36) & 0.67 \\
Combined ranges & 6.5 & 30 (out of 36) & 0.23 \\
\hline
\end{tabular}


benefits accrue at multiple geographical scales. Again, the influence of potential local exploitation under the Tribal Rights Act was not assessed within the current study.

\section{DISCUSSION}

At the very least, representation of the value of the range of ecosystem services provided by SGNP, both in monetary and non-monetary terms, challenges the commonplace undervaluation of many ecosystem services and the consequent frequency with which they are overlooked in decision-making (Sutherland et al., 2018).

\section{Benefits and beneficiaries of services generated by SGNP}

ESI analyses, illustrative as they are at ecosystem service category level, highlight the diversity and multiplicity of societal values that stem from current management of SGNP. Controls on exploitation of provisioning services play a role in retaining ecosystem structure and functioning, enhancing flows of a range of desired and co-beneficial supporting, regulating and cultural services. Benefits accrue at scales from the local to the international, weighted towards local/city scales but with important benefits right up to global scale. Many provisioning and some cultural services have established financial values, however lack of market valuation of most supporting and regulating services represents a major market failure contributing to unsustainable exploitation (Science for Environment Policy, 2015).

Table 3 outlines the beneficiaries of services produced by SGNP. On the basis of these findings, Supplementary Online Material 3 breaks down services identified as relevant to SGNP into the eight categories of:

1. Tangible and monetisable services amenable to market development;

2. Tangible services requiring more work to develop and/or hard to quantify;

3. Tangible but technically illegal services, such as fuelwood and timber extraction, that nonetheless are currently utilised;

4. Tangible but banned services for which highly controlled market expansion could be considered;

5. Services for which there are already de facto PES or PES-like arrangements (the state recirculates taxpayer revenues for public good);

6. Services for which further research is required to understand benefits and possible PES or PES-like arrangements;

7. Services that are both banned and inappropriate; and
8. Services that should not be marketed due to risk of double-counting of benefits.

\section{PES as a potential contributor to addressing pressures on the SGNP ecosystem}

Major threats to the SGNP ecosystem described in the SGNP (2012) Management Plan include:

1. Destruction of natural habitats due to encroachment and illicit tree cutting;

2. Activities of communities in padas within SGNP disturbing adjacent areas (Wildlife and We Protection Foundation, 2018), though rights remain unclear under the Tribal Rights Act;

3. Disturbances to natural habitats by mining (mainly stone quarrying) in areas immediately adjacent to the park's external boundaries;

4. Human-animal conflict, mainly involving leopards (panthers); and

5. Insufficient space for leopards, compounded by attraction to peripheral garbage and domestic animals, leading to the dispersal of young panthers outside the protected area, contributing to increased mortality (for example by speeding vehicles), and other problems.

Despite the diversity and value of services produced by the SGNP ecosystem, almost all are overlooked in the SGNP (2012) Management Plan. Demonstration of the full range of values provided by SGNP, both economic and non-monetary including some clearly used by local communities, can contribute to curbing these and other threats through their integration into positive management. When forest ecosystem services are regarded as free and are consequently ignored or underestimated, forest use, management or conversion contributes to substantial forest degradation and loss observed globally (Jenkins \& Schaap, 2018). Conservation and effective management of ecosystems for sustaining services requires innovative approaches and enabling policies. PES approaches, applied to identified beneficial services, offer an additional approach for recognition and management of services provided by SGNP.

\section{Opportunities for PES development}

Cells in the right-hand 'Recommendations' column of Supplementary Online Material 3 are colour-coded using a three-colour 'traffic lights' approach, also annotated with status: READY (green) signifies ready for market development; FURTHER DEVELOPMENT (amber) indicates that further research or dialogue is necessary to explore potential PES arrangements; whilst NO POTENTIAL (red) indicates no potential for 
development of PES arrangements. In each cell is a recommendation for PES development, further exploration of potential PES arrangements, or abandonment of the notion of PES development for each service.

In practice, contractual arrangements for many PES schemes globally are 'input-based', founded on agreed practices deemed by partners in the PES arrangement as likely to produce the desired benefit(s), rather than 'output-based' (geared directly to quantified outcomes) (Smith et al., 2013). Further major challenges remain over the quantification and attribution of ecosystem services and their link to the values of different social groups in complex social-ecological systems at relevant spatial and temporal scales (Spash, 2009; Reed et al., 2015). Monetary valuation of ecosystem services has been widely used to place values on ecosystem services in the context of PES. However, monetisation techniques tend to overlook the value of cultural services, as well as the values of ecosystem services that are shared by different social groups as opposed to the aggregation of individual values (Kenter et al., 2015). Assignment of monetary values also tends to overlook the ways in which values may change over time for different groups, for example due to environmental, social, economic or technological change. Bundling and layering help to resolve issues of quantification and attribution in PES schemes by quantifying and valuing a number of different ecosystem services at the same time, linked to a specific intervention (Smith et al., 2013). Despite progress in recent years towards the development of bundled and layered PES schemes seeking to resolve conservation and rural development goals, four important challenges remain unresolved when considering potential PES arrangements in SGNP:

1. PES schemes have often incentivised management activities to maximise production of a narrow outcome, or set of outcomes. This is due both to knowledge gaps about the impacts on linked ecosystem services, as well as the asymmetric influence of PES scheme proponents (Pattanayak et al., 2010);

2. Interdependencies between ecological and social systems have often been overlooked, with the primary focus of PES design then potentially resulting in negative social outcomes (for example Roe et al., 2013). Contributory factors include: i) measurement issues related to the intangible nature of many cultural services (Chan et al., 2012); ii) ontological issues related to whether values for these services are held individually or collectively, and hence whether a single value can be ascribed to an ecosystem service in any given location addressing the perspectives of all societal groups (Kenter et al., 2015); and iii) philosophical issues over whether cultural services could or should be monetised via PES schemes (Fourcade, 2011);

3. Governance of PES schemes in such complex socialecological systems remains challenging (Farley \& Costanza, 2010; Bennett \& Gosnell, 2015), relating to the inter-connected and quite different spatial and temporal scales at which different ecosystem services are typically managed (Schomers et al., 2015; Jones et al., 2016). PES schemes are most effective when developed with bottom-up involvement of local communities, particularly in international development contexts (e.g. Milder et al., 2010) and involving linking institutions (Shapiro-Garza et al., 2020a; He, 2020; Joslin, 2020); and

4. The current focus on excluding resource extraction can conflict with indigenous rights under the Tribal Rights Act, so some accommodation of limited and controlled resource extraction, zoned or otherwise guided to protect important and vulnerable ecosystems and processes, may represent a means to resolve conservation and tribal rights priorities.

This study identifies ecosystem services for which it may be possible to develop PES arrangements, though it does not detail the necessary follow-on stages of actual PES development. In practice, identifying ecosystem services with clear potential providers and consumers and then resolving institutional, legal and technical issues can be highly complex. Further research is required to determine the distributional benefits and costs of management options, resolving the rights and priorities of different stakeholders some of which are currently regarded as conflicting. Key features to be integrated into PES design include accounting for knowledge gaps, ensuring additionality (cost-effectively providing ecosystem services that would not have otherwise been provided), avoiding 'environmental leakage' (preventing additionality within the project area in ways that displace impacts to other areas), ensuring permanence of outcomes and payments, avoiding transaction costs disproportional to the intended benefits, and establishing PES arrangement where there is a low level of, or uncertain, land ownership or rights. Stepwise approaches are therefore necessary requiring adequate resourcing, including time, financial investment and appropriate expertise, including involvement of institutions effective in engaging and integrating different stakeholder groups. A stepwise approach to PES development was published by the UK Government (Smith et al., 2013), with an alternative 10-step approach to assessing the feasibility of PES provided by Fripp (2014). Correctly framed, PES arrangements can 
not only secure public benefits, but also address poverty alleviation. Carefully designed and implemented PES schemes represent just one of a range of policy tools that can synergistically complement environmental policy mixes. Consequently, the majority of PES schemes in developing countries tend to be government -financed on behalf of a range of public beneficiaries, with progressive schemes integrating conservation and development goals.

\section{CONCLUSIONS}

Sanjay Gandhi National Park hosts a wealth of biological and geological diversity and cultural history, conferring a wide range of benefits locally, into the surrounding city, nationally and internationally, and spanning a diversity of values from the tangible and tradeable to the cultural and spiritual.

The ecosystem services framework provides a useful basis for stratifying the diverse and qualitatively differing benefits generated by SGNP, the RAWES (Rapid Assessment of Wetland Ecosystem Services) approach helping identify the perceived values of all linked services in semi-quantitative terms.

Ecosystem services were assessed as either: closer to PES implementation and development; requiring further research or dialogue to explore potential PES arrangements; or with no potential for development of PES arrangements.

The RAWES approach also enables articulation of the range of geographical scales over which SGNP provides benefits to society, demonstrating the value of continued or increasing protection and management of the park's natural and heritage assets.

Impacts of a variety of pressures on the park could have deleterious effects on the park ecosystems and their associated values, though there may be scope for limited and carefully controlled resource extraction for the subsistence needs of indigenous communities.

\section{SUPPLEMENTARY ONLINE MATERIALS}

SOM 1 - Opportunities for investment in the societal values provided by Sanjay Gandhi National Park, India SOM 2 - RAWES-based analysis of perceived ecosystem service benefits, geographical scales, potential PES arrangements and some explanatory comments.

SOM 3 - Consideration of potential PES arrangements for service generated by the Sanjay Gandhi National Park, India

\section{ABOUT THE AUTHORS}

Mark Everard has been working on ecosystem services since the late 1980s, both in development of underlying concepts and in practical application in developed and developing world settings including providing guidance to governments and practitioners. Mark has published extensively (over 110 peer-reviewed papers, 29 books and many technical and popular press articles), and regularly contributes to television and radio. A substantial part of Mark's work is in India, but has encompassed wider regions of South Asia, East and Southern Africa, as well as Australia, Europe and the USA. Mark has specific interests in wetlands, water and sustainable development.

Anwar Ahmad is the Chief Conservator of Forests and Director, Sanjay Gandhi National Park, Mumbai, Maharashtra, India. Sanjay Gandhi National Park spans $87 \mathrm{~km}^{2}$ of protected area, established in 1996 with headquarters in Borivali.

Nudrat Zawar Sayed is National Coordinator of the Wildlife and We Protection Foundation, established with the objectives to protect and conserve wildlife in India and in other parts of the world by raising awareness amongst the people by holding programmes, conferences and seminars for better coexistence with humans.

Shivaji Chavan is Director of the Wildlife and We Protection Foundation, established with the objectives to protect and conserve wildlife in India and in other parts of the world by raising awareness amongst the people by holding programmes, conferences and seminars for better coexistence with humans.

\section{REFERENCES}

Bennett, D.E. and Gosnell, H. (2015). Integrating multiple perspectives on payments for ecosystem services through a social-ecological systems framework. Ecological Economics 116:172-181. DOI: https://doi.org/10.1016/ j.ecolecon.2015.04.019.

Braat, L.C. and de Groot, R. (2012). The ecosystem services agenda: Bridging the worlds of natural science and economics, conservation and development, and public and private policy. Ecosystem Services 1: 4-15. DOI: https:// doi.org/10.1016/j.ecoser.2012.07.011.

Brockington, D. and Wilkie, D. (2015). Protected areas and poverty. Philosophical Transactions of the Royal Society B: Biological Sciences 370(1681):20140271. DOI: 10.1098/ rstb.2014.0271.

Brondizio, E.S., Settele, J., Díaz, S. and Ngo, H.T. (2019). Global Assessment on Biodiversity and Ecosystem Services of the Intergovernmental Science-Policy Platform on Biodiversity and Ecosystem Services (IPBES). Intergovernmental Science -Policy Platform on Biodiversity and Ecosystem Services 
(IPBES). (https://www.ipbes.net/global-assessmentbiodiversity-ecosystem-services, accessed 14 March 2020).

Butchart, S.H.M., Walpole, M., Collen, B., et al. (2010). Global Biodiversity: Indicators of Recent Declines. Science 328:1164 -1168. DOI: https://doi.org/10.1126/science.1187512.

Chan, K.M., Satterfield, T. and Goldstein, J. (2012). Rethinking ecosystem services to better address and navigate cultural values. Ecological Economics 74 8-18. DOI: DOI: https:// doi.org/10.1016/j.ecolecon.2011.11.011.

Corbera, E., Costedoat, S., Ezzine-de-Blas, D. and Van Hecken, G. (2020). Troubled Encounters: Payments for Ecosystem Services in Chiapas, Mexico. Development and Change 51 (1): 167-195.

Cubbage, F., Harou, P. and Sills, E. (2007). Policy instruments to enhance multi-functional forest management. Forest Policy and Economics 9: 833-851.

Ekins, P., Simon, S., Deutsch, L., Folke, C. and De Groot, R. (2003). A framework for the practical application of the concepts of critical natural capital and strong sustainability. Ecological Economics 44: 165-185. DOI: https:// doi.org/10.1016/S0921-8009(02)00272-0.

Engel, S., Pagiola, S. and Wunder, S. (2008). Designing payments for environmental services in theory and practice: An overview of the issues. Ecological Economics 65: 663-674. DOI: https://doi.org/10.1016/j.ecolecon.2008.03.011.

Everard, M. (2009). Ecosystem services case studies. Environment Agency Science report SCHO0409BPVM-E-E. Environment Agency, Bristol. (https://www.gov.uk/ government/uploads/system/uploads/attachment_data/ file/291631/scho0409bpvm-e-e.pdf, accessed 14 March 2020).

Everard, M., Kangabam, R., Tiwari, M.K., Mclnnes, R.J., Kumar, R., Talukdar, G.H., Dixon, H., Joshi, P., Allan, R., Joshi, D. and Das, L. (2019). Ecosystem service assessment of selected wetlands of Kolkata and the Indian Gangetic Delta: Multi-beneficial systems under differentiated management stress. Wetlands Ecology and Management 27(2): 405-426. DOI: https://doi.org/10.1007/s11273-019-09668-1.

Everard, M. and Waters, R.D. (2013). Ecosystem services assessment: How to do one in practice. Institution of Environmental Sciences, London. (https://www.the-ies.org/ sites/default/files/reports/ecosystem_services.pdf, accessed 14 March 2020).

FAO (2007). The State of Food and Agriculture 2007: Paying Farmers for Environmental Services. Food and Agricultural Organization of the United Nations, Rome. (ftp://ftp.fao.org/ docrep/fao/010/a1200e/a1200e00.pdf, accessed 14 March 2020).

Farley, J. and Costanza, R. (2010). Payments for ecosystem services: From local to global. Ecological Economics, 69, 2060-2068. DOI: https://doi.org/10.1016/ j.ecolecon.2010.06.010.

Figgis, P., Mackey, B., Fitzsimons, J., Irving, J. and Clarke, P. (editors). (2015). Valuing Nature: Protected Areas and Ecosystem Services. Science Informing Policy Symposium Series, Australian Committee for IUCN, Ultimo, New South Wales.

Fourcade, M. (2011). Cents and sensibility: Economic valuation and the nature of "nature". American Journal of Sociology 16 (1): 721-727.
Fripp, E., Liswanti, N., Tjoa, M. and Silaya, T. (2014). Payment for Ecosystem Services (PES): Assessment of PES Potential in Seram Island. Working Paper 166. Bogor, Indonesia: CIFOR.

Greenleaf, M. (2020). Rubber and Carbon: Opportunity Costs, Incentives and Ecosystem Services in Acre, Brazil. Development and Change 51(1): 51-72.

Gross-Camp, N.D., Martin, A., Mcguire, S., Kebede, B. and Munyarukaza, J. (2012). Payments for ecosystem services in an African protected area: Exploring issues of legitimacy, fairness, equity and effectiveness. Oryx 46(1): 24-33. DOI: https://doi.org/10.1017/S0030605311001372.

$\mathrm{He}$, J. (2020). Situated payments for ecosystem services: Local agencies in the implementation of the sloping land conversion programme in Southwest China. Development and Change 51 (1): 73-93.

Hubermann, D. (2009). A gateway to PES: Using payments for ecosystem services for livelihoods and landscapes. Markets and incentives for livelihoods and landscapes series No. 1, Forest Conservation Programme. Gland: International Union for the Conservation of Nature (IUCN).

Hummel, C., Poursanidis, D., Orenstein, D., Elliott, M., Adamescu, M.C., Cazacu, C., Ziv, G., Chrysoulakis, N., van der Meer, J. and Hummel, H. (2019). Protected area management: Fusion and confusion with the ecosystem services approach. Science of the Total Environment 651(2): 2432-2443. DOI: https:// doi.org/10.1016/j.scitotenv.2018.10.033.

IUCN. (2015). Sanjay Gandhi National Park: The Heart and Lungs of a Wild Mumbai. The International Union for Conservation of Nature (IUCN), Gland. https://www.iucn.org/content/sanjaygandhi-national-park-heart-and-lungs-wild-mumbai, accessed 14 March 2020).

Jackson, S. and Palmer, L. (2014). 'Reconceptualising ecosystem services: Possibilities for cultivating and valuing the ethics and practices of care', Progress in Human Geography 39(2): 122145.

Jenkins, M. and Schaap, B. (2018). Forest Ecosystem Services: Background study prepared for the thirteenth session of the United Nations Forum on Forests. United Nations Secretariat. (https://www.un.org/esa/forests/wp-content/uploads/2018/05/ UNFF13_BkgdStudy_ForestsEcoServices.pdf, accessed 11 April 2020).

Jones, L., Norton, L., Austin, Z., Browne, A.L., Donovan, D., Emmett, B.A., Grabowski, Z. J., Howard, D.C., Jones, J.P.G., Kenter, J.O., Manley, W., Morris, C., Robinson, D.A., Short, C., Siriwardena, G.M., Stevens, C.J., Storkey, J., Waters, R.D. and Willis, G.F. (2016). Stocks and flows of natural and human-derived capital in ecosystem services. Land Use Policy 52: 151-162. DOI: https://doi.org/10.1016/ j.landusepol.2015.12.014.

Joslin, A. (2020). Translating water fund payments for ecosystem services in the Ecuadorian Andes. Development and Change 51(1): 94-116.

Kenter, J.O., O’Brien, L., Hockley, N., Ravenscroft, N., Fazey, I., Irvine, K.N., Reed, M.S.,Christie, M., Brady, E., Bryce, R., Church, A., Cooper, N., Davies, A., Evely, A., Everard, M., Jobstvogt, N., Molloy, C., Orchard-Webb, J., Ranger, S., Ryan, M. and Watson, V. (2015). What are shared and social values of ecosystems? Ecological Economics 111: 86-99. DOI: https://doi.org/10.1016/j.ecolecon.2015.01.006. 
Martín-López, B., García-Llorente, M., Palomo, I. and Montes, C. (2011). The conservation against development paradigm in protected areas: Valuation of ecosystem services in the Doñana social-ecological system (southwestern Spain). Ecological Economics 70(8): 1481-1491. DOI: https:// doi.org/10.1016/j.ecolecon.2011.03.009.

McElwee, P., Huber, B. and Vân Nguyễn, T.H. (2020). Hybrid outcomes of payments for ecosystem services policies in Vietnam: Between theory and practice. Development and Change 51(1): 253-280.

Mclnnes, R.J. and Everard, M. (2017). Rapid Assessment of Wetland Ecosystem Services (RAWES): An example from Colombo, Sri Lanka. Ecosystem Services 25: 89-105. DOI: https://doi.org/10.1016/j.ecoser.2017.03.024.

Merlo, M. and Briales, E.R. (2000). Public goods and externalities linked to Mediterranean forests: Economic nature and policy. Land Use Policy 17: 197-208. DOI: https://doi.org/10.1016/ S0264-8377(00)00017-X

Milder, J.C., Scherr, S.J. and Bracer, C. (2010). Trends and future potential of payment for ecosystem services to alleviate rural poverty in developing countries. Ecology and Society 15(2): 4 [online] DOI: https://doi.org/10.5751/ES-03098-150204.

Millennium Ecosystem Assessment (2005). Ecosystems and Human Well-being: Synthesis. Island Press.

MoEF (2016). Environment Ministry issues final notification on Eco -Sensitive Zone in Sanjay Gandhi National Park, Mumbai. Press Information Bureau, Ministry of Environment, Forest and Climate Change (MoEF), Government of India. (http:// pib.nic.in/newsite/PrintRelease. aspx?relid=154962, accessed 14 March 2020).

Nelson, S.H., Bremer, L.L., Meza Prado, K. and Brauman, K.A. (2020). The political life of natural infrastructure: Water funds and alternative histories of payments for ecosystem services in Valle del Cauca, Colombia. Development and Change 51 (1): $26-50$.

OECD (2010). Paying for biodiversity: Enhancing the costeffectiveness of payments for ecosystem services. OECD: Paris.

Pattanayak, S., Wunder, S. and Ferraro, P. (2010). Show me the money: Do payments supply environmental services in developing countries? Review of Environmental Economics and Policy 4(2): 254-274. DOI: https://doi.org/10.1093/reep/ req006.

Ramsar Convention (2018). Resolution XIII.17: Rapidly assessing wetland ecosystem services. 13th Meeting of the Conference of the Contracting Parties to the Ramsar Convention on Wetlands. Ramsar Convention Secretariat, Gland. (https:// www.ramsar.org/about/cop13-resolutions, accessed 14 March 2020).

Ramsar Convention Secretariat. (2007). The Ramsar concept of "wise use". Ramsar Information Paper No.7, Ramsar Convention Secretariat, Gland. (https://www.ramsar.org/sites/ default/files/documents/library/info2007-07-e.pdf, accessed 11 April 2020).

Reed, M.S., Stringer, L.C., Dougill, A.J., Perkins, J.S., Athopheng, J.R., Mulale, K. and Favretto, N. (2015). Reorienting land degradation towards sustainable land management: Linking sustainable livelihoods with ecosystem services in rangeland systems. Journal of Environmental Management 151: 472485. DOI: https://doi.org/10.1016/j.jenvman.2014.11.010.
Roe, D., Elliott, J., Sandbrook, C. and Walpole, M. (2013). Biodiversity conservation and poverty alleviation: Exploring the evidence for a link. Wiley Blackwell. DOI: https:// doi.org/10.1002/9781118428351.

Schomers, S., Matzdorf, B., Meyer, C. and Sattler, C. (2015). How local intermediaries improve the effectiveness of public payment for ecosystem services programs: The role of networks and agri-environmental assistance. Sustainability 7 (10): 13856-13886. DOI: https://doi.org/10.3390/su71013856.

Science for Environment Policy. (2015). Ecosystem Services and the Environment. In-depth Report 11 produced for the European Commission, DG Environment by the Science Communication Unit, UWE, Bristol. (https://ec.europa.eu/ environment/integration/research/newsalert/pdf/ ecosystem_services_biodiversity_IR11_en.pdf, accessed 14 March 2020).

Secretariat of the Convention on Biological Diversity. (2008). Protected Areas in Today's World: Their Values and Benefits for the Welfare of the Planet. Montreal, Technical Series no. 36, i-vii + 96 pages. (https://www.cbd.int/doc/publications/cbdts-36-en.pdf, accessed 14 March 2020).

Sen, A. and Pattanaik, S. (2015). Alienation, conflict, and conservation in the Protected Areas of urban metropolis: A case study of Sanjay Gandhi National Park, Mumbai. Sociological Bulletin 64(3) 375-395.

SGNP (2012). Management Plan of Sanjay Gandhi National Park, 2013-14 to 2022-23. Unpublished report by the Forest Department, Maharashtra.

Shapiro-Garza, E. (2020). An alternative theorization of payments for ecosystem services from Mexico: Origins and Influence. Development and Change 51(1): 196-223.

Shapiro Garza, E., McElwee, P., Van Hecken, G. and Corbera, E. (2020). Beyond market logics: Payments for ecosystem services as alternative development practices in the Global South. Development and Change 51(1): 3-25. DOI: https:// doi.org/10.1111/dech.12546.

Smith, S., Rowcroft, P., Everard, M., Couldrick, L., Reed, M., Rogers, H., Quick, T., Eves, C. and White, C. (2013). Payments for ecosystem services: A best practice guide. Department for Environment, Food and Rural Affairs, London.

Spash, C.L. (2007). Deliberative monetary valuation (DMV): Issues in combining economic and political processes to value environmental change. Ecological Economics 63(4): 690-699. DOI: https://doi.org/10.1016/j.ecolecon.2007.02.014.

Sutherland, I.J., Villamagna, A.M., Dallaire, C.O., Bennett, E.M., Chin, A.T.M., Yeung, A.C.Y., Lamothe, C.A., Tomscha, S.A. and Cormier, R. (2018). Undervalued and under pressure: A plea for greater attention toward regulating ecosystem services. Ecological Indicators 94(2): 23-32. DOI: https:// doi.org/10.1016/j.ecolind.2017.06.047.

TEEB (2010). The Economics of Ecosystems and Biodiversity Ecological and Economic Foundations. Earthscan: London and Washington.

Upton, C. (2020). Conserving Natures? Co producing payments for ecosystem services in Mongolian rangelands. Development and Change 51(1): 224-252.

Verma, M., Negandhi, D., Khanna, C., Edgaonkar, A., David, A., Kadekodi, G., Costanza, R. and Singh, R. (2015). Economic Valuation of Tiger Reserves in India: A Value+ Approach. Indian Institute of Forest Management. Bhopal, India. January 
2015. (http://iifm.ac.in/wp-content/uploads/2016/06/IIFMNTCA-REPORT.compressed-min.pdf, accessed 14 March 2020).

vonHedemann, N. (2020). Transitions in payments for ecosystem services in Guatemala: Embedding forestry incentives into rural development value systems. Development and Change 51(1): 117-143.

Wildlife and We Protection Foundation (2018). Mapping of hutment (encroachment) in Sanjay Gandhi National Park. Wildlife and We Protection Foundation, Borivali.
Wunder, S. (2005). Payments for environmental services: Some nuts and bolts. Center for International Forestry Research Occasional Paper No. 42 [online] available at: www.cifor.org/ publications/pdf_files/OccPapers/OP-42.pdf

WWF (2009). Watershed-Based Payments for Ecosystem Services in the Humid Forest of Madagascar. Worldwide Fund for Nature. (http://wwf.panda.org/who_we_are/wwf_offices/ madagascar/?uProjectID=MG0921\#, accessed 14 March 2020).

\section{RESUMEN}

El Parque Nacional Sanjay Gandhi (SGNP, por sus siglas en inglés), rodeado por la megalópolis de Bombay, India, está sujeto a altas presiones antropogénicas. Sin embargo, constituye un importante "pulmón verde" y una fuente vital de agua, que apoyan la biodiversidad, el turismo, la recreación y otros beneficios tanto a nivel local como remoto. Para salvaguardar y mejorar el ecosistema del parque, es preciso reconocer y demostrar la diversidad de valores asociados a estos múltiples beneficios, identificar los posibles conflictos y establecer las medidas de gestión necesarias para protegerlos. Este estudio explora los resultados del SGNP a través de un abanico de servicios de los ecosistemas conectados en forma sistemática, y las escalas geográficas en las que se obtienen los beneficios de dichos servicios. Esto informa acerca de posibles nuevas oportunidades de "pago por los servicios de los ecosistemas" (PSE). La condición de protección del paisaje se refleja en los bajos valores de los servicios de aprovisionamiento (explotación energética o de materiales), pero en valores sustanciales en términos de los servicios de apoyo (como el hábitat para la vida silvestre), de regulación (incluyendo el clima mundial, el microclima y la regulación hidrológica) y culturales (particularmente el turismo). Sin embargo, el aprovechamiento directo de los recursos por parte de las comunidades que habitan el parque es limitado. Se identificaron algunos servicios de los ecosistemas como listos para la implementación de PSE (por ejemplo, el suministro de agua), otros requieren un mayor desarrollo (incluyendo las contribuciones al microclima urbano periférico), mientras que para muchos servicios el potencial de PSE es nulo o limitado (como la extracción de madera o de agregados, que está prohibida en virtud de los reglamentos del parque).

\section{RÉSUMÉ}

Le parc national de Sanjay Gandhi, entouré par la mégapole de Mumbai en Inde, est soumis à de fortes pressions anthropiques. Cependant, il constitue un important 'poumon vert' ainsi qu'une source d'eau, soutenant la biodiversité, le tourisme, les loisirs et de nombreux autres avantages à portée à la fois locale et plus distante . Pour sauvegarder et améliorer l'écosystème du parc, il est nécessaire d'identifier puis de mettre en évidence la diversité des valeurs associées à ces multiples avantages, de repérer les conflits potentiels et d'établir les mesures de gestion nécessaires pour les protéger. Afin d'explorer les résultats du parc, cette étude examine une gamme de services écosystémiques interconnectés et les échelles géographiques auxquelles les avantages de ces services reviennent. Cela met en lumière de nouvelles possibilités de 'paiement pour des services rendus par les écosystèmes' (PSE). Le statut protégé du parc se manifeste à travers la faible valeur attachée aux services de fourniture (exploitation matérielle ou énergétique), contrairement à la valeur substantielle attachée aux services de soutien (à l'habitat de la faune par exemple), à la réglementation (y compris le climat mondial, le microclimat et la régulation hydrologique) et aux services culturels (en particulier le tourisme). Cependant, l'exploitation directe des ressources par les communautés habitant le parc reste limitée. Certains services écosystémiques sont considérés comme prêts pour la mise en œuvre du PSE (par exemple l'approvisionnement en eau), d'autres nécessitent un développement supplémentaire (telles les contributions au microclimat urbain périphérique), tandis que de nombreux services ont un potentiel de PSE inexistant ou limité (comme l'extraction de bois ou d'agrégats, interdit en vertu des règlements du parc). 